\title{
BRICS' Sustainable Development Dialog: Framing Contours to a Common Agenda through the Intragroup Trade ${ }^{1}$
}

\author{
N. Khmelevskaya
}

Natalia Khmelevskaya - PhD, Associate professor, Moscow State Institute of International Relations of Ministry of Foreign Affairs of Russia; 76 Vernadskogo av., 119454, Moscow, Russian Federation; E-mail: Khmelevskaya@mgimo.ru

\begin{abstract}
This article explores the formation of multilateral dialogue among the BRICS grouping of Brazil, Russia, India, China and South Africa to address the problems of development quality based on the most demonstrative sphere of the countries' economic cooperation - mutual trade.

The foreign policy contour of the BRICS dialogue is a shared responsibility and stems from national obligations within the United Nations (UN) system, the World Trade Organization (WTO) and other international fora. As it connects with development strategies in different environments and at different paces, the convergence of the positions taken by BRICS members both within and outside the forum is in line with their domestic economic priorities, and hence multilateral cooperation mechanisms are included in national development plans. The external economic contour poses similar restrictions on internal development agricultural and manufacturing industries based on the exploitation of natural resources, the use of dirty fuels, ecologically intensive exports and the general need to preserve and restore the resource base.

Analytically, this study is based on the quantitative parameters of intra-BRICS trade from 2009-2017, the BRICS export resource-intensity indicators and non-tariff restrictions statistics. Maintaining relatively similar and generally low tariffs in raw materials sectors, BRICS countries regulate the turnover of "green" goods within the group through technical barriers, price control measures and quality standards, maintaining a consistently high share of environmentally intensive raw materials. At the same time, given the differentiation of BRICS countries in terms of quality of growth and sensitivity to external shocks, some of them seek to diversify their exports (oil and petroleum products from Russia and China), while others protect local producers (agricultural products from Brazil and Russia), and take "green economy" measures as a substitute for higher tariffs for environmentally friendly goods to help retain markets.
\end{abstract}

Key words: BRICS; Sustainable Development Goals (SDGs); Bilateral Trade; Trade Related Aspects of a Green Economy; Non-Tariff Measures (MTM); Carbon Dioxide Emissions Embodied in Export

For citation: Khmelevskaya N. (2018) BRICS' Sustainable Development Dialog: Framing Contours to a Common Agenda through the Intragroup Trade. International Organisations Research Journal, vol. 13, no 4, pp. 74-95 (in English). DOI: 10.17323/1996-7845-2018-04-04.

\section{Introduction}

The objective of sustainable and long-term development satisfying the needs of the present generation while not depriving future generations of the opportunity to meet their needs

${ }^{1}$ The editorial board received the article in April 2018. 
[UN General Assembly, 1987, p. 24] was announced for the first time in the World Commission on Environment and Development (WCED) report "Our Common Future." This report was revolutionary for its time, and has of course differently affected the scope of resource exploitation, directions of technical development and structural changes in the BRICS grouping of Brazil, Russia, India, China and South Africa. The pressing need for all BRICS members to improve the quality of their people's lives and to overcome development gaps through economic growth has not always been coordinated with their environmental capabilities; hence, the burden on natural resources is one of the common points in the national development strategies of the BRICS states.

A common problem for the BRICS in terms of the quality of development is also that, in the words of the WCED report, "a world in which poverty is endemic will always be prone to ecological and other catastrophes" [UN General Assembly, 1987, pp. 24, 143]. According to the Organisation for Economic Co-operation and Development (OECD), despite significant progress in combating poverty in all BRICS countries, stratification of their societies remains high. The maximum Gini coefficient for OECD countries at 0.5 [OECD, 2015, p. 20] is average for the BRICS. ${ }^{2}$ Despite the absolute importance of economic growth for the eradication of poverty in developing countries, given the current income distribution, growth in the BRICS may not affect most households' incomes due to restrictions on the gross domestic product (GDP) redistribution channels and low elasticity of links between poverty and inequality, and also between poverty and income [Fosu, 2010, pp. 16-27]. While the expansion of BRICS economies has for a long time determined the increase in the population's income mainly through budgetary channels [Lustig, 2015], the redistribution of incomes from foreign trade accompanied by the BRICS' integration into global economic ties and structural shifts in the private sector often act as stressors for social stability [OECD, 2014, pp. 68-71].

The progress in trade and investment relations within the BRICS, initially embodied in expanding mutual exports (on average its aggregate volume multiplied throughout 2009-2014 relative to 2009), ${ }^{3}$ and then in the importance of their local markets as complementing (for China and India) or replenishing (for Brazil and Russia) the compression of external demand in 2013-2016, can serve the purposes of further growth in the BRICS. At the same time, the exponential fall in prices for energy resources and basic commodities in 2013-2016 affected the physical parameters of BRICS economies with kaleidoscopic speed, depending on export dependence and inclusion in global value chains, thereby determining the quality of the BRICS development models and giving impetus to redistribution of incomes from Brazilian, Russian and South African exporters to Indian and Chinese importers, as well as leading to instability of trade and investment within the BRICS.

This research focuses on the impact of multilateral cooperation mechanisms on national development strategies and their benchmarks, and the resulting BRICS dialogue aimed at sharing best practices and technologies for sustainable and balanced growth, taking into account the most demonstrative achievements of their economic engagement in the trade area. ${ }^{4}$

${ }^{2}$ Author's estimations based on OECD data [2015, pp. 19-21].

${ }^{3}$ Author's estimations based on International Trade Centre data [n.d.].

${ }^{4}$ Given the growing importance of environmental problems in the sphere of subsoil use and nature management, during its BRICS presidency in 2015, Russia proposed a number of initiatives. See BRICS [n.d.]. 


\section{The Global Contours of the BRICS' Dialogue on Sustainable Development}

The dynamic development of the BRICS economies, which has no analogues in terms of pace - even taking into account the negative growth of Brazil and Russia in 2013-2016, the average annual GDP growth rates in the BRICS were almost four times higher than in the Group of 7 (G7) in 2000-20175 - and which has brought their share in the global economy closer to that of developed countries, ${ }^{6}$ has been inevitably accompanied by profound changes in all spheres of natural resources exploitation and human activity.

The adjustment of BRICS development models to environmentally friendly growth aimed at reducing poverty and facilitating the well-being of present and future generations (see Table 1) occurred in different environments and at different paces. In Brazil, India and South Africa with complex, multilayered and fragmented social structures, distinctive society polarization, and economic inequality, such an adjustment was impossible without broad political and economic transformations. The turn to inclusive growth in Brazil was gaining strength in President Lula da Silva's "human-oriented" modernization of 2003-2010, accompanied by the combination of economic liberalism with social reforms [Okuneva, 2008, pp. 753-68]. During that period, Brazil managed to halve extreme poverty (the poverty rate based on the purchasing power power (PPP) threshold of $\$ 1.25$ a day decreased from $4.2 \%$ to $2.1 \%)^{7}$ and the absolute numbers of chronically undernourished people have also declined [FAO, 2014b].

In India and South Africa, the enclave type of development has for a long time restrained the quality of economic growth: after 11 five-year national development plans aimed at eliminating poverty ("pro-poor growth"), by the end of 2012 the poverty rate in India was lowered by almost $20 \%$ while the gap between the layers of society continued to broaden (the Gini coefficient continued to grow until 2015) [UNDP, n.d.]. ${ }^{8}$ As of today, one-third of India's population, as well as $41 \%$ of South Africans, continue to face greater restrictions and deprivations than people in other BRICS countries (see Multidimensional Poverty Index in Table 1). One in four urban and one in three rural inhabitants still live below the poverty line, and only $21 \%$ of those living in rural areas have access to basic sanitation [Anand et al., 2014, pp. 48-56]. According to Food and Agriculture Organization (FAO) estimates, $31.4 \%$ of India's and $13.2 \%$ of South Africa's populations are chronically undernourished. ${ }^{9}$ At the same time, Russia and China were the first BRICS countries to eliminate hunger. Reorientation of the development models to domestic demand in Russia and China is largely explained by the fiasco of the market in the distribution of growth benefits (inequality) and global challenges.

The 1987 WCED report also highlighted sustainable development policies such as human resources, food security, ecosystems, energy, industry and urbanization [United Nations General Assembly, 1987, pp. 27-34], which became the guiding principles of the

\footnotetext{
${ }^{5}$ Author's estimations based on IMF data [n.d.].

${ }^{6}$ At the end of 2014, the total BRICS purchasing power parity (PPP)-based GDP equaled that of the G7, and taking into account the recession in 2013-2016 they together produced about 33\% of the global GDP in 2016, while 39 countries from the IMF analytical group "Developed Economies" produced 40.6\% (calculated by the author based on data from the IMF [n.d.]).

${ }^{7}$ Based on the official UN [n.d.a] site for the MDG indicators.

${ }^{8}$ Based on Multidimensional Poverty Index (MPI) data in the UNDP statistical database [n.d.].

${ }^{9}$ Based on data from the Food Security Portal [n.d.].
} 
Table 1. MDGs Achievement Indicators in BRICS Countries

\begin{tabular}{|c|c|c|c|c|c|c|c|}
\hline \multirow[t]{2}{*}{ Country } & MDG 1 & MDG 2 & MDG 3 & MDG 4 & MDG 5 & MDG 6 & MDG 7 \\
\hline & $\begin{array}{c}\text { Multidimensional } \\
\text { Poverty Index } \\
\text { (MPI)* }\end{array}$ & $\begin{array}{l}\text { Net primary } \\
\text { education } \\
\text { enrollment } \\
\text { ratio, girls } \\
\text { and boys }\end{array}$ & $\begin{array}{c}\text { Gender } \\
\text { Inequality } \\
\text { Index } \\
(\mathrm{GII})^{* *}\end{array}$ & $\begin{array}{l}\text { Under-five } \\
\text { mortality } \\
\text { rate, per } \\
1,000 \\
\text { children }\end{array}$ & $\begin{array}{c}\text { Maternal } \\
\text { death ratio, per } \\
100,000 \text { live } \\
\text { births }\end{array}$ & $\begin{array}{l}\text { HIV prevalence } \\
\text { among } \\
\text { population } \\
\text { aged } 15-49 \\
\text { years, } \%\end{array}$ & $\begin{array}{c}\mathrm{CO} 2 \\
\text { emissions } \\
\text { per capita, } \\
\text { tons }\end{array}$ \\
\hline Brazil & 0.010 & $96 * * *$ & 0.441 & 16.4 & 44 & 0.6 & 2.5 \\
\hline Russia & $\mathrm{n} / \mathrm{a}$ & 97.2 & 0.314 & 9.6 & 25 & $\mathrm{n} / \mathrm{a}$ & 12.5 \\
\hline India & 0.282 & 98.9 & 0.563 & 47.7 & 174 & 0.3 & 1.6 \\
\hline China & 0.23 & 86.9 & 0.202 & 10.7 & 27 & $\mathrm{n} / \mathrm{a}$ & 7.6 \\
\hline $\begin{array}{l}\text { South } \\
\text { Africa }\end{array}$ & 0.41 & 90.5 & 0.461 & 41.9 & 138 & 19.2 & 8.9 \\
\hline
\end{tabular}

Notes:

* For the first time, used in the United Nations Development Program (UNDP) Human Development Report 2010, the MPI identifies and shows the average number of poor people capturing overlapping deprivations they face in three dimensions - living standards, health and education. Data on the MPI are from the UNDP statistical database [n.d.].

** Reflects the unfavourable situation for women in three areas: reproductive health, empowerment and economic activity. Data on the GII are from the UNDP statistical database [n.d.]. *** at end-2006

Source: Based on United Nations Statistics Division data (as of 1 January 2017) [n.d.].

final declaration of the first United Nations Conference on Environment and Development (The Earth Summit) in June 1992 in Rio de Janeiro [UN, 1992b]. In turn, the Earth Summit Rio Declaration for the first time outlined the anthropocentric nature of sustainable development (principles 1, 10, 11 [UN, 1992a]), pointing out that trade policy measures taken for environmental protection can serve as a means of discrimination and hidden protectionism, and therefore the approach that "the polluter should... bear the costs... without distorting international trade and investment" was agreed upon (principles 12, 16 [UN, 1992a]).

For developing BRICS countries, the principle of common but differentiated responsibilities for global environmental degradation [UN, 1992a] manifested in the Rio Declaration has become both unifying and divergent. Being the two largest greenhouse gas emitters of the world, China and India have repeatedly stressed that, despite their rapid industrial growth, their per capita emissions are lower than those in advanced countries and they need economic growth to address social and economic development problems [Government of India Ministry of Environment and Forests, 2011]. On 21 October 2009, at a joint symposium on national plans to counter climate change held in New Delhi, China and India signed the Agreement on Cooperation on Addressing Climate Change and established the bilateral Working Group on Climate Change, which holds annual meetings alternately in the two countries [Government of India Prime Minister's Office, 2015].

At the next United Nations Summit on Sustainable Development "Rio+10" in 2002 in Johannesburg, special attention was paid to social aspects of sustainable development, with practical guidelines in this area formulated in the Rio de Janeiro Agenda 21 and the UN Millennium Declaration, and known as the millennium development goals (MDGs) 
[World Summit on Sustainable Development, 2002]. The most acute MDGs for BRICS countries at the time were: to provide all people with an opportunity to earn on a sustainable basis and to halve by 2015 the proportion of people living on less than $\$ 1.25$ a day; to protect the vulnerable and halve the proportion of people without access to basic sanitation; to integrate the principles of environmental sustainability into national strategies; to minimize industrial harm to human health and the environment; and to preserve and rationally use exhaustible natural resources.

During that period, BRICS members and other developing countries established more than 300 public-private partnerships ${ }^{10}$ with large companies, producer associations and non-governmental organizations as part of the agenda for businesses inclusion into national strategies (see Table 2). At the same time, the first International Conference on Financing for Development was held in Monterrey (18-22 March 2002), where international trade became a key issue for discussion both as a driver of economic growth and employment, and as an important external source of financing for development [United Nations, 2002, p. 9-12].

For the first time, the issue of trade barriers and non-tariff measures that limit access for emerging economies (for example, to agricultural markets of developed countries) and lead to global trade imbalances was included in the resume of the declaration and linked to the World Trade Organization (WTO) negotiations agenda at a meeting in Doha. There, delegates proposed to expand access to agricultural markets through the principle of less-than-full reciprocity in the framework of the exemptions for Article XXVIII of the GATT [UN General Assembly, 2001, pp. 3-6]. Thus, the relationship between WTO rules and countries' obligations under multilateral environmental agreements has clearly been reflected in the impact of environmental measures on access to markets [UN General Assembly, 2001, p. 10].

The contours of the initially fragmented dialogue on sustainable development issues between the BRICS states were shaped at the multilateral cooperation platforms of the UN and WTO system. The rapprochement of political and diplomatic positions of the members clearly resulted from internal economic priorities, and therefore occurred primarily between China and Brazil, and between Brazil and India. The former pair united around increasing the effectiveness of official development assistance and partnership between donor countries (consistency, coherence, accountability [UN, 2002, pp. 37, 55]). The latter almost fully agreed on the priority of eradicating poverty, investing in social projects and infrastructure [UN, 2002, p. 73]. The Russian position ${ }^{11}$ was to acknowledge national responsibility for the development process, and to consider external support not as a permanent factor, but as a means of assistance [UN, 2002, p. 45]. Access to developed countries' markets for goods, services and capital has become a unifying issue for all BRICS members.

The same reasons resulted in the multi-vector and multi-format BRICS dialogue on the particularly sensitive climate change agenda. The Bali Roadmap and Action Plan with a list of Nationally Appropriate Mitigation Actions (NAMA) was adopted at the United Nations Climate Change Conference on 15 December 2007. Similarly to the subsequent Copenhagen

\footnotetext{
${ }^{10}$ Based on the data from the official UN portal. Available at: http://www.un.org/ru/events/pastevents/ wssd.shtml (accessed at 20 October 2018).

${ }^{11}$ The round table where this provision was approved, was also attended by the Common Fund for Commodities (CFC), the Joint United Nations Programme on HIV/AIDS (UNAIDS), the Eurasian Economic Union (EEC), the International Chamber of Commerce (ICC), the World Confederation of Labour and the Brazilian Institute for Socioeconomic Studies.
} 
(2009) and Cancun (2010) agreements, it attempted to record voluntary commitments and actions by countries aimed at reducing emissions. Having directly participated in the development of these documents, India and China announced that they do not associate themselves with the agreements, and thus can coordinate implementation of certain measures among themselves [UN, 2015, Article 7.2 para. (c)]. Russia made its participation conditional on the participation of the largest greenhouse gas emitters, China and the United States. Finally, BRICS representatives gathered for a separate preliminary meeting, where they nevertheless reached a consensus on the legally binding nature of the agreement. ${ }^{12}$

Since 2013, an informal BRICS advisory group has been working within the FAO, which is formalized by the BRICS leaders [BRICS Leaders, 2014, p. 36]. Following the UN conference in Copenhagen (2009), the BRICS has focused on the relationship between climate change and food security, the recognition of great importance of traditional knowledge and clean technologies, and the need to transfer best practices within the group [BRICS Leaders, 2015].

Within the framework of expanded responsibilities, the governments participating in the UN conferences on sustainable development were invited to develop national sustainable development strategies and a system of specialized agencies. Brazil was the first among the BRICS countries to establish the Commission on Environment and Sustainable Development (18 March 2004, Comissão de Meio Ambiente e Desenvolvimento Sustentável, CMADS). In 2007, the India Council for Sustainable Development began its work. In 2008, the South African national sustainable development network was launched which prepared the South African Sustainable Development Strategy (2009-2014) approved by the government in November 2011. In Russia and China, several specialized agencies are engaged in work on a sustainable development agenda: the National Development and Reform Commission, the Ministry of Science and Technology and the Ministry of Environmental Protection.

Additionally, BRICS countries have developed support programs and incentives for the transition to the "green economy" as integral parts of their national development strategies (see Table 2). Renewable energy sources have become the focus of special "green" programmes of state support in Brazil (PROINFA (Table 2)), India (National Mission for a Green India) and South Africa (Renewable Energy Independent Power Producer Procurement Programme). State support in China is aimed at controlling industrial pollution, promoting the rational use of water and land resources, energy and natural resources, and industrial waste management as part of the programme to combat climate change in Russia, India, China and South Africa (see Table 2).

The declaration of the 2012 Rio+20 conference entitled "The Future We Want" contained the greatest number of practical recommendations and guidelines for sustainable development in history [UN General Assembly, 2012] - from the proclamation of a "green economy" as one of the means to achieve sustainable development and eradicate poverty to the adoption of action programme with a set of financial support measures and summit decisions. It also established the UN System Task Team on the post-2015 UN development agenda which managed the transition from the MDGs to the sustainable development goals (SDGs). BRICS countries conduct active public consultations on all 17 SDG thematic areas ${ }^{13}$ in the framework of international initiatives and national dialogue platforms (see Table 2).

\footnotetext{
${ }^{12}$ Based on data from the Climate Action Network [n.d.].

${ }^{13}$ See UN [n.d.b] for more detail.
} 


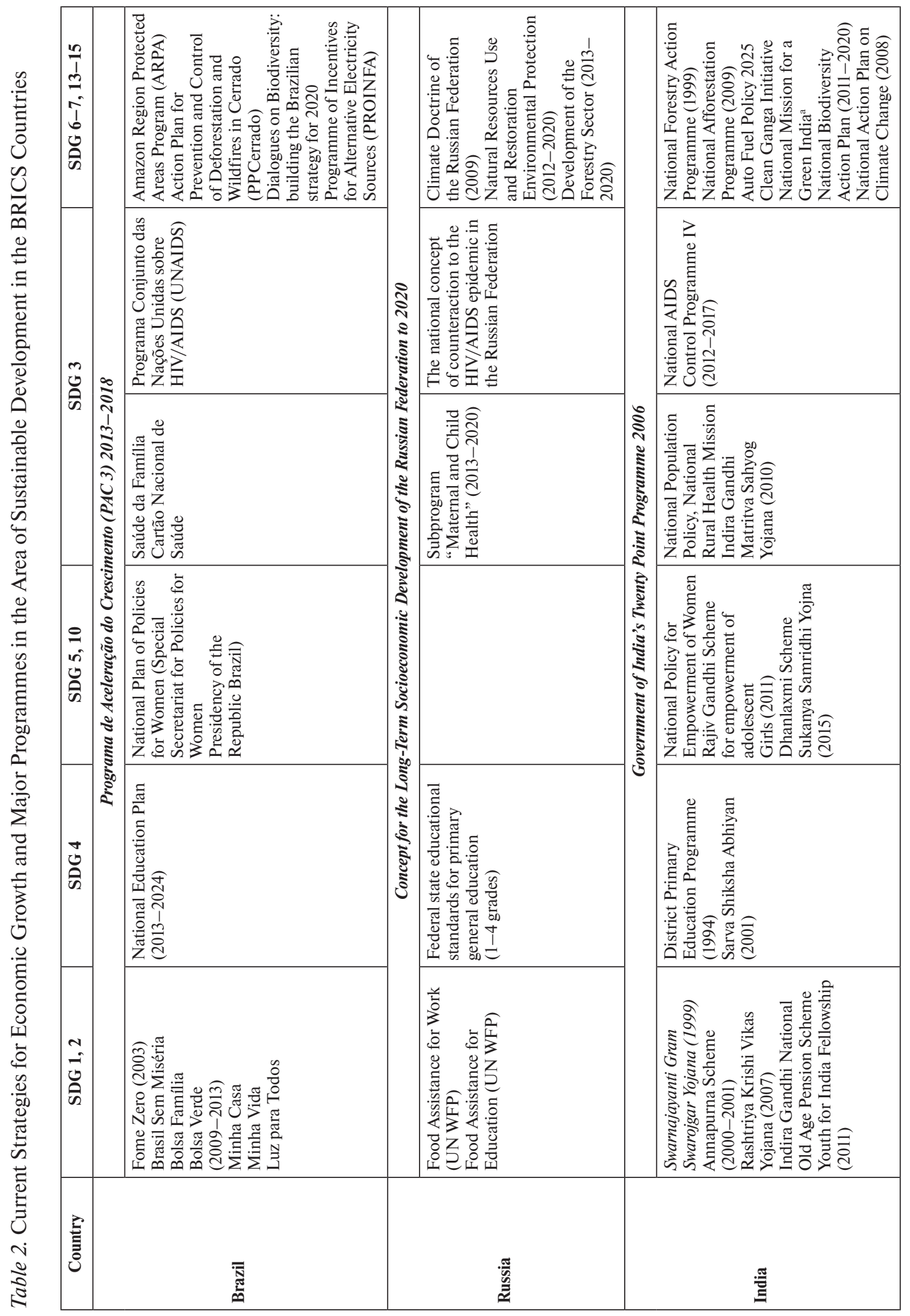




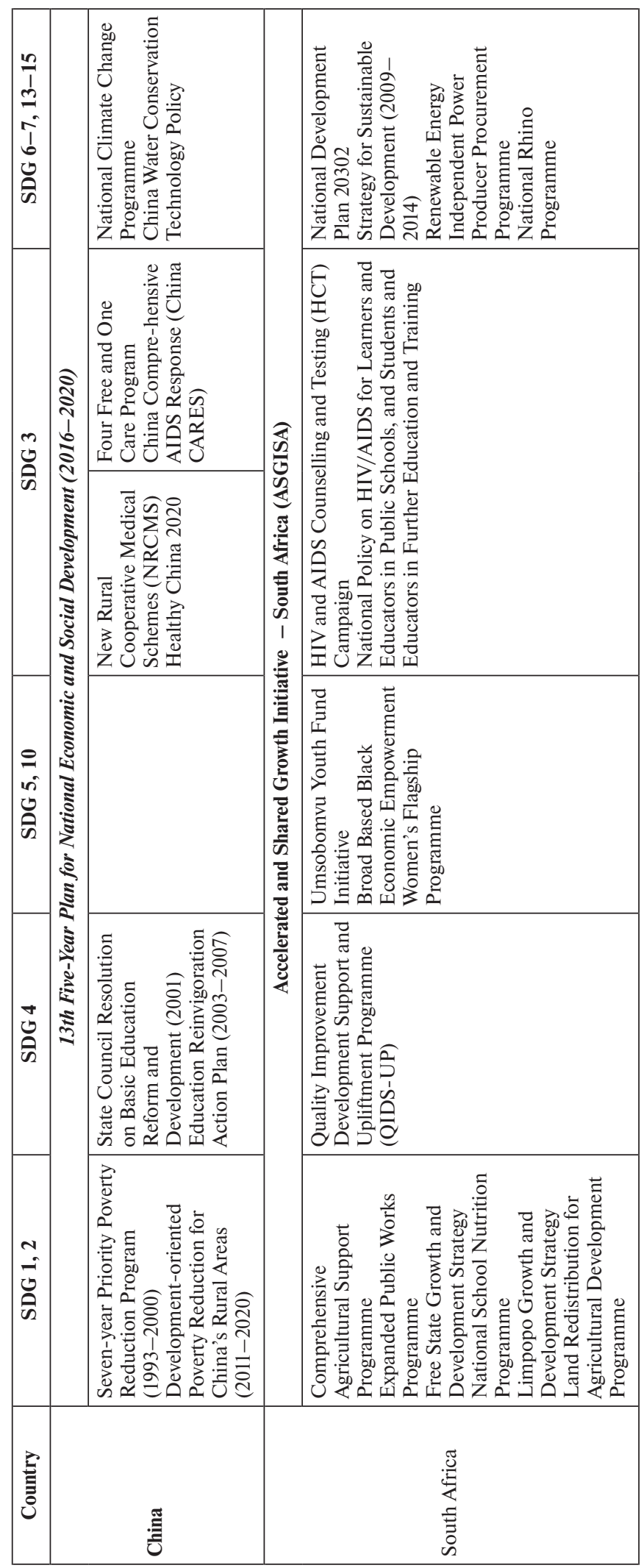

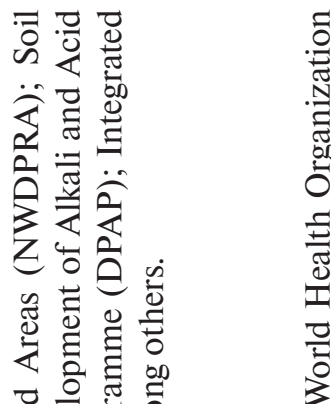

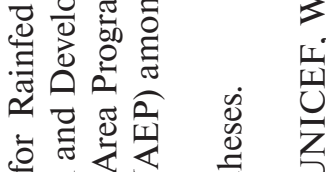

응

. 흥 흘

ป 2.0

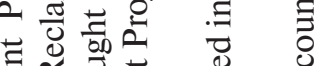

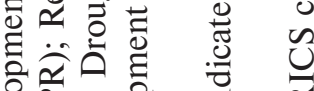

잉这高

ดั

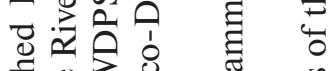

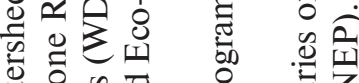

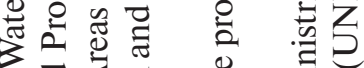

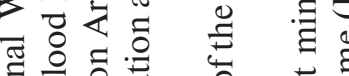

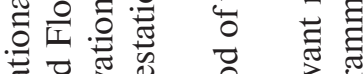

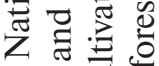

๙

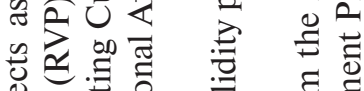

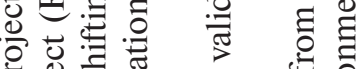

은. ํㅡㄴ

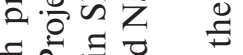

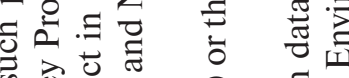

क 仓

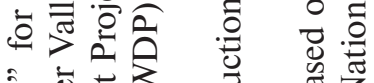

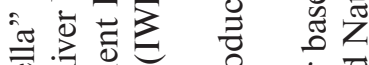

일

氖

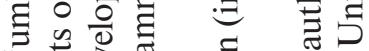

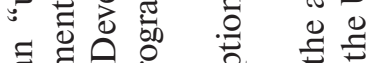

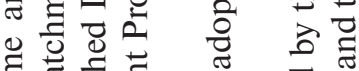

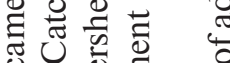

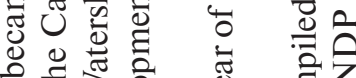

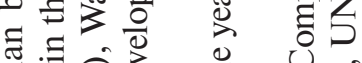

完.

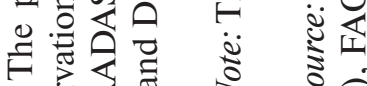

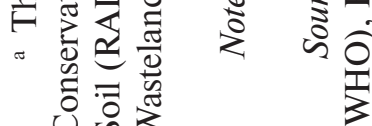


Thus, aligning specific BRICS interests in the dialogue on sustainable development is based on socially oriented growth and environmentally friendly development goals, while the MDGs (now SDGs) and national commitments to mitigate and adapt to climate change shape its outer contour. Taking a shared responsibility within the framework of multilateral environmental agreements and trade rules, BRICS countries affect global consumption and production, and at the same time reflect a number of parameters of such obligations in the internal development programs.

\section{BRICS' Intragroup Trade for Complementing National Interests in Sustainable Development Dialog}

The deepening of trade and investment ties between BRICS countries, accompanied by the growing importance of their local export markets as complementing external demand (for China and India) and replenishing it (for Brazil and Russia), was initially based on their goods' complementarity under relatively weak intra-group competition [Khmelevskaya, 2015a]. This relates to Brazilian meat products in the Russian and South African markets, components for power equipment produced in China, and Russian electrical equipment and gas turbine engines in other BRICS countries.

It was in mutual trade (2009-2014) that the results of the initial stage of BRICS development became clear - in terms of overall export growth, Russia and Brazil were second after China, expanding both their trade ties (extensive growth) and export mix (intensive growth) [Khmelevskaya, 2015a, p. 46]. The divergence of external shock effects in 2013-2017 primarily emphasized the structural weaknesses of the BRICS states along with the differences in their foreign trade agendas - the retention of export positions or seeking import substitution, expansion or intensification of commodity flows. That is why more and more fine-tuning is needed now for the already established set of cooperation mechanisms and a "broad-based dialogue" within the BRICS, both through the involvement of interested people (and most importantly, representatives of professional associations) to address specific problems and through the implementation of "cross-cutting" development projects.

In line with the priorities of each presidency and using the multilateral negotiations format adopted in the WTO, the BRICS trade and economic cooperation agenda has been discussed since 2011 at the meetings of economic and trade ministers and the BRICS Contact Group on Economic and Trade Issues - since 2015, at the meetings of natural resources and ecology ministers, energy ministers, ministers of industry, and heads of BRICS competition authorities, and since 2016, at the meetings of labour and employment ministers and heads of customs authorities. In 2016, BRICS launched and tested a new public-private partnership tool - the BRICS Environmentally Sound Technology (BEST) Platform. At the same time, specialized working groups have appeared within the BRICS on competition issues research (2012), information and communications technology (2016), e-commerce (2017), environment (2018) ${ }^{14}$ and others.

Real demands of civil society and practical proposals on the BRICS trade and investment agenda have been articulated by the BRICS Business Forum since 2010 and the BRICS Business Council since 2013, by the Civil Forum, the Parliamentary Forum and

${ }^{14}$ The memorandum on the establishment of the group was agreed upon during the meeting of the BRICS environment ministers on 13-16 September in Goa, and the first full-scale meeting of the group was held on 17 May 2018 in Durban. 
the BRICS Youth Summit since 2015, and by the BRICS Universities League, the BRICS Network University and the Women Parliamentarians' Forum since 2016. In 2018, the Forum for the Exchange of Technologies and Innovations for Small and Medium-sized Enterprises and the Science, Technology and Innovation Women's Forum were established. Their activities are aligned with addressing the development of women's entrepreneurship and increasing productivity, and therefore, ultimately, with a need to reorient national development models toward inclusive and balanced innovational growth, which is now important for all BRICS members.

Trade policy measures are among the main barriers to intra-BRICS trade, business and investment [Khmelevskaya, 2015b, p. 106], and in the raw materials sector all members have relatively similar general levels of tariffs. In turn, impeding the sale of goods at prices that do not yield sufficient profits and increasing the burden on environmental systems, trade barriers encourage countries to increase exports of depletable resources, preserving low productivity and constraining the update of fixed assets. Almost twofold growth of Russian exports to the BRICS (by $80 \%$ in 2009-2014) ${ }^{15}$ explained by crude oil and petroleum products supplies (constituting about half of all exports to the BRICS in 2014). In the wake of the fall in energy prices in 2014-early 2015, China increased imports of crude oil from Russia and Brazil, becoming the second-largest buyer of petroleum products from the latter country. Despite the overall decline in intra-BRICS trade in 2013-2016, the Chinese share in India's foreign trade grew due to a multiple increase in Indian exports of oil distillation products, copper and chemical products [Khmelevskaya, 2015a].

The ability of countries to improve access to new and environmentally friendly goods, services and technologies through international trade and, as a result, to more effectively allocate limited natural resources, was recognized at the summits in Rio de Janeiro and Johannesburg. The fail-safe support for multiple complex links between sustainable development and international trade is the focus of many international institutions. For their part, they provide an international legal regime for about 200 multilateral environmental agreements, with more than 20 using trade-related measures to limit damage to the environment and human health while achieving their goals [UNEP, IISD, 2005, pp. 14-8].

The BRICS countries participate ${ }^{16}$ in the Convention on International Trade in Endangered Species of Wild Fauna and Flora (CITES, 3 March 1973), the Vienna Convention for the Protection of the Ozone Layer (22 March 1985) and the Montreal Protocol on Substances that Deplete the Ozone Layer (16 September 1987), the Basel Convention on the Control of Transboundary Movements of Hazardous Wastes and Their Disposal (22 March 1989), the Convention on Biological Diversity (5 June 1992), the Stockholm Convention on Persistent Organic Pollutants (23 May 2001), the Rotterdam Convention on the Prior Informed Consent Procedure for Certain Hazardous Chemicals and Pesticides in International Trade (10 September 1998) and the United Nations Framework Convention on Climate Change (12 December 2015), all of which directly define trade-related regulatory measures. Today, Russia is the only BRICS country that has not ratified the Framework Convention on Climate Change adopted in Paris on 12 December 2015 by 195 countries and containing commitments to reduce greenhouse gas emissions in order to keep the temperature rise within $2^{\circ} \mathrm{C}$ and limit temperature growth by $1.5^{\circ} \mathrm{C}$ [UN, 2015, p. 2].

Realizing that the impact of trade on the environment depends on the complementarity of their objectives and their orientation towards mutual support, international trade

\footnotetext{
${ }^{15}$ Author's estimations based on data from International Trade Centre [n.d.].
}

${ }^{16}$ As of 13 June 2018. 
and commodity organizations (the WTO, the UN Conference on Trade and Development (UNCTAD), the World Customs Organization (WCO), International Sugar Organization (ISO), the International Cocoa Organization (ICCO), the International Organization of Vine and Wine (OIV), etc.) support the concept of sustainable development both in their fundamental multilateral agreements and in their arbitration practices and standards. For example, the longest and most complex trade disputes within the WTO were related to the environment: from protecting the sea turtle population from accidental catches by industrial fisheries to protecting human health from risks caused by the use of asbestos or the storage of used tires. The history of using the WTO as a platform for protecting the "green interests" of BRICS national economies (except Russia, which joined the pretrial WTO trade disputes settlement mechanism only in 2012) began almost from the moment of its establishment. The first case considered by this mechanism was the dispute over reformulated gasoline between Venezuela, Brazil and the United States. The decision on this case determined that the WTO General Agreement on Tariffs and Trade (GATT) should not be interpreted in isolation from public international law [WTO, 1996], and thus it served as a precedent for including the provisions of multilateral environmental agreements when interpreting the provisions of the international trade organizations law.

In a dispute between the European Union and Brazil about retreaded tires in 2005, Brazil justified the imposition of restrictions on tire imports (not applicable to Mercosur and Venezuela) by arguing that because of the reduced period of using such tires, they are causing greater damage to the environment [WTO, 2009]. The proceedings resonated widely with the public because for the first time non-governmental environmental organizations of different levels (the Center for International Environmental Law, the Brazilian branch of the World Wildlife Fund and the Brazilian Forum for Environment and Development) joined and presented their independent expert opinions to the WTO. The reports of the then Brazilian Minister of the Environment Marina Silva (second by the number of votes in the first round of the presidential elections in Brazil in 2014) and the then "responsible officer" of the Brazilian ministry of foreign affairs and current WTO Director-General Roberto Azevedo, were often accompanied by vivid and emotionally colourful presentations. Additionally, for the first time the rules for promoting free and fair trade were applied from the standpoint of environmental protection and their correlation with it [Kadysheva, 2013] meanwhile Argentina, Mexico, Paraguay and China joined the WTO panel discussion on its side to show solidarity with Brazil in that point.

Given the absence of free trade agreements between the BRICS countries or their integration groupings, the WTO today is the only effective format for both bilateral and comprehensive dialogues on the trade aspects of sustainable development. In their joint summit declarations, BRICS leaders have also repeatedly reaffirmed the mandate of UNCTAD as an institution responsible for trade, investment, finance and technology issues in the context of development [BRICS Leaders, 2014, p. 12]. All BRICS countries are members and participants of key WCO agreements in the field of customs affairs. They are also members of many commodity organizations (the International Organization for Standardization and others): ${ }^{17}$ Russia and Brazil are members of the International Coffee Organization (ICO), Russia and India are members of the International Grain Council (IGC), and Brazil, Russia and India are members of the ICCO [Khmelevskaya, 2014].

${ }^{17}$ For more information on the activities of international commodity organizations see Khmelevskaya [2014]. 
WTO rules and practice are primarily aimed at maintaining a critically important balance: on the one hand, the sovereign right of WTO members to use certain measures to protect their national interests is inviolable; on the other hand, it is necessary to ensure that WTO members do not abuse this right by using it to mask protectionist measures in the process of interpreting and applying exemptions provided for in Article XX, both general and those aimed at protecting people's lives, their health and the viability of animals and plants $^{18}$ [Bernasconi-Osterwalder et al., 2012, pp. 319, 322-325]. In addition, the Agreement on Sanitary and Phytosanitary Measures and the Agreement on Technical Barriers to Trade of the WTO expand the list of such measures to precautionary ones. Their application is conditioned by international custom and practice, and therefore is often hidden and looks like the imposition of administrative barriers. The WTO Agreement on Subsidies and Countervailing Measures (SCM) and the Agreement on Agriculture contain a special safeguards for agricultural imports. The former also contains the category of non-actionable subsidies (Article 8), ${ }^{19}$ including the financing of "green" technologies and innovations.

"Green economy" measures promoting the development of a low-carbon economy and stimulating sustainable management in agriculture and forestry are becoming more complicated each year. This includes the transition from controversial countervailing duties and salvage fees to WTO-approved "green" public procurement [WTO, 2011] and voluntary quality standards. It also includes the formation of an "environmentally friendly goods" category attributable to a new market-oriented type of regulation [UNEP, IISD, 2014, pp. 13-4]. According to UNCTAD, over a third of global imports are subject to a variety of technical barriers - from inspection requirements to assessments of safety and quality parameters. Every sixth product must meet sanitary standards [UNCTAD, 2013, p. 3-5]. Moreover, these standards are increasingly confirming their protective assignment, while developed high-income countries hide selective protectionism behind technical barriers (they regulate access to $65 \%$ of imported goods, which is half as much as in Africa, and twice as high as in Asia and Latin America). ${ }^{20}$

The problem of preserving and restoring the resource base is both the national priority of BRICS states and the focus of the BRICS multilateral dialogue since its launch: more than $40 \%$ of the world's forests and a third of the world's arable land are located in Brazil, Russia, India and China. ${ }^{21}$ In 2000-2008, more than half of the global increment of government expenditures on forest maintenance was provided by China and India [FAO, 2016, p. 39]. The BRICS forestry sector employs from 147,000 people in South Africa to 3.841 million in China, while the production of industrial wood, paper and pulp, and wood processing provides from $0.8 \%$ (Russia) to $1.7 \%$ (India) of GDP [FAO, 2014a, pp. 121-28]. At the same time, in agriculture and forestry, which are fully based on the exploitation of natural and climatic resources, such measures are considered for their potential economic and social consequences affecting almost one in four of the world's inhabitants (judging by the general BRICS population).

Agricultural production in the BRICS is a significant source of greenhouse gas emissions (it accounts for up to $10 \%$ of global emissions in carbon dioxide equivalent) ${ }^{22} \mathrm{Al}-$ though the share of emissions from agriculture and forestry in the total amount of anthro-

\footnotetext{
${ }^{18}$ See more details at WTO [n.d.a].

${ }^{19}$ See more details at WTO [n.d.b].

${ }^{20}$ Author's estimations based on data in UNCTAD [2013].

${ }^{21}$ Based on data in FAO [2014a].

${ }^{22}$ Based on data from FAOSTAT database [FAO, n.d.].
} 
pogenic emissions is decreasing, due to the emissions generated by the use of synthetic fertilizers in agriculture (with a share of 13\%) and fossil fuels in other sectors, greenhouse gas emissions are growing. ${ }^{23}$ Total exports of $\mathrm{CO} 2$-equivalent from China to developed countries decreased from 827 million tons in 2002-2007 to 229 million tons in 2007-2012 [Pan et al., 2017, p. 935] both as a result of decreasing commodity exports growth and its lower resource intensity, but mainly in line with structural changes in the economy (in particular, reduced consumption of solid fuels and lower energy intensity of production). Further, seasonal factors and the consequences of global climate change (rising temperature, droughts, natural disasters) have a radical impact on this sector - deforestation occurs at the fastest pace in Brazil which is actively involving tropical forests in agricultural production [FAO, 2016, p. 18].

In turn, unilateral "green" trade measures are increasingly becoming a tool for segmenting markets or protecting local producers from international competition. The decrease in the ecological intensity of 109 countries' exports in 1988-2013 was accompanied by an increase in the overall level of tariff load for finished goods [Kono, 2017], thus reducing the effects of tariff escalation. The reasons for the solidarity of India and China on "green" trade measures became obvious. They believe that such measures often contradict international trade rules and therefore require equal treatment for similar goods, that they can be used for hidden protectionism, and that they undermine the principle of common but differentiated responsibility of countries at different levels of development [Ares et al., 2009, pp. 13-8].

For BRICS countries, the likelihood that similar protection measures can be used to hide protectionism within the group is growing (see Fig. 1a). This includes consistent introduction of safety and quality standards (Brazil and Russia), technical barriers (Brazil), and price control measures (China) along with a sharp drop in the number of anti-dumping investigations and dominance of ecologically intensive raw materials and semi-finished products in foreign trade (see Fig. 1b). China's emissions export volumes are estimated to reach 2,116.4 million tons per year, Russia's -540.7 million tons, India's -319 tons and Brazil's - 66.6 tons [Makarov, Sokolova, 2014, p. 494].

On the one hand, the main items of Russian exports within the BRICS have the highest carbon intensity: oil and petroleum products provide $61 \%$ of Russia's exports accounting for more than $58 \%$ of all BRICS fuel imports, ${ }^{24}$ along with fertilizers and forestry products. Then come oil, mining and metallurgical products supplied by South Africa and organic chemistry exports from India. On the other hand, taking into account the weakness of BRICS export positions on the mutual markets [Khmelevskaya, 2015a], Russian emissions imports from China have substantially increased over the last decade (from 10\% to 38\%) [Makarov, Sokolova, 2014, p. 493]. Open BRICS economies have differently experienced the reversal of the global development cycle trajectory in 2013-2016. In Brazil and Russia, there was a recession, in South Africa there was stagnation; China experienced a slowdown, while India continued to grow [IMF, 2018, pp. 2-3].

Consequently, given the differentiation of the BRICS countries in terms of the quality of their growth and sensitivity to external shocks, market-oriented "green economy" regulation is increasingly becoming a way of segmenting markets (of oil and petroleum products in Russia and China) and protecting local producers from international compet-

${ }^{23}$ For example, according to FAO calculations, greenhouse gas emissions resulting from biological processes in paddy fields account for $10 \%$ of total emissions in agriculture.

${ }^{24}$ Calculated as of end-2014 based on data from International Trade Centre [n.d.]. 


\section{(a)}

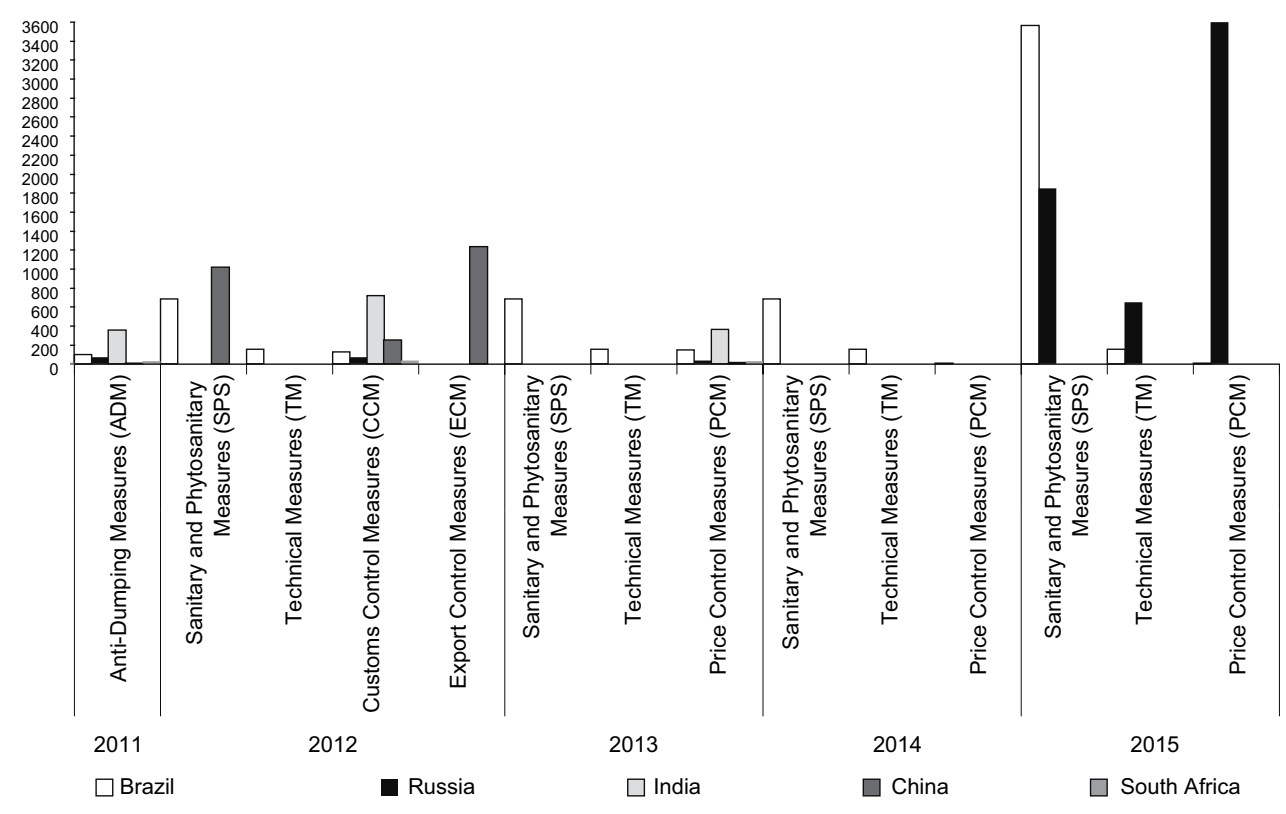

(b)

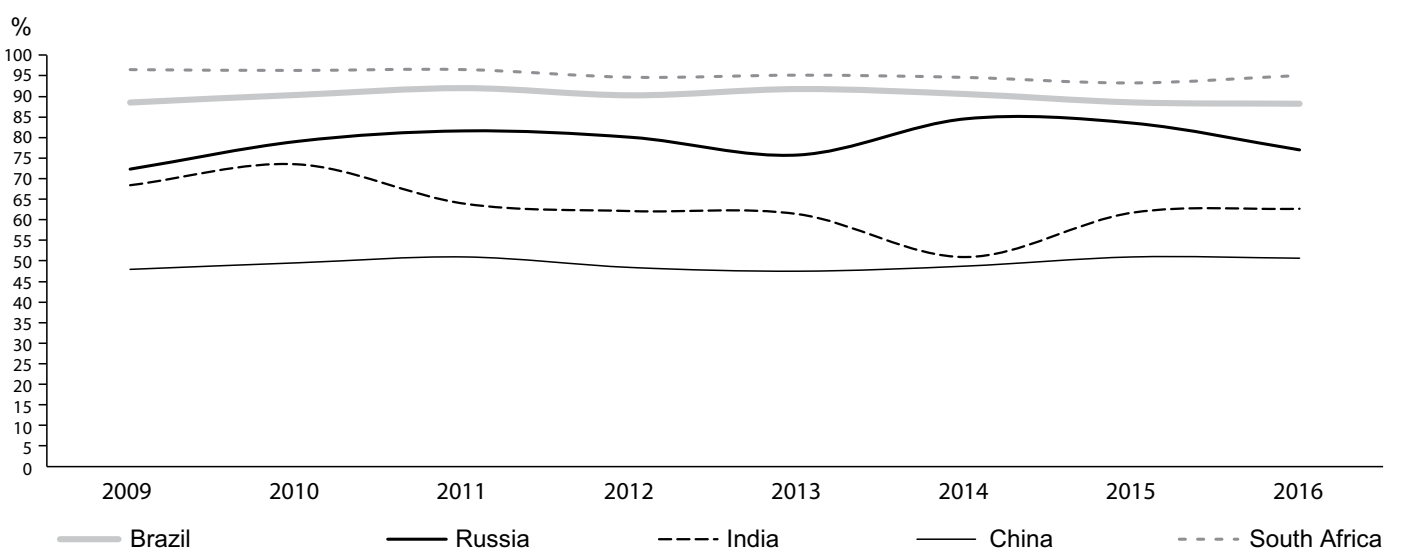

Fig. 1. Non-tariff Trade Measures* (a) and Environmentally Intensive Exports within the BRICS** (b) in 2009-2016

Notes:

* The number of regulated goods.

** Share of categories "Raw materials and intermediate products" (OECD classification) in intra-BRICS exports (\%).

Source: Calculated and compiled by the author based on the World Integrated Trade Solution software $^{25}$ and the OECD statistical database [n.d.].

${ }^{25}$ The World Integrated Trade Solution (WITS) software provides multiple access to trade, tariff and non-tariff databases of UNCTAD, International Trade Center (ITC), United Nations Statistical Division (UNSD) and the World Trade Organization (WTO) [WITS, n.d.]. 
ition (for agricultural products from Brazil and Russia). For today's development models in China, India and South Africa, the relationship between economic expansion and carbon dioxide equivalent emissions is already weakly significant in terms of environmental risks and threats, even if their annual increment of $5 \%$ to $10 \%$ is taken into account [Azevedo et al., 2018, p. 114]. For Brazil and Russia, national development patterns still increase GHG emissions extensively.

The issue of dirty fuels used in transportation, industry and production of environmentally friendly goods purchased in the framework of social assistance and state population support programmes is also relevant. For example, India blocked the entry into force of the WTO Trade Facilitation Agreement in 2014 until it received a waiver (provisional exemption) related to the rules for creating food stocks, ie., when food is purchased from small producers at inflated prices with its subsequent sale in the local market at a lower price. In turn, China and Russia participate in multilateral negotiations on the Environmental Goods Agreement based on a list of 54 products $^{26}$ compiled by the Asia-Pacific Economic Cooperation countries and approved at the 2012 Vladivostok summit (including wind turbines, air quality controllers, solar panels and other goods demandable in the local BRICS markets).

\section{Conclusion}

The foreign policy contour of the BRICS dialogue on sustainable development is set within the UN system, the WTO, and other international fora based on a shared responsibility and national obligations in the framework of international agreements and multilateral regulations. As its alignment with development strategies occurs in different environments and at different paces, the convergence of positions both within and outside the BRICS forum is in line with their intra-economic priorities, and hence multilateral cooperation mechanisms are included in national development plans: the transition of Russia and China to growth based on domestic demand is accompanied by increased participation in cross-cutting infrastructure projects and supranational institutions, while overcoming the same structural constraints in Brazil and South Africa is largely based on integration opportunities.

Broader involvement of intra-BRICS foreign trade relations in addressing the problems of quality development is partly hampered by the absence of free trade agreements, as evidenced by the practice of applying hidden trade measures in the BRICS in 2011-2016. Maintaining relatively similar low tariff loads in raw materials sectors, BRICS countries hinder the turnover of "green" goods within the association through non-tariff measures technical barriers and price control measures along with a sharp drop in the number of anti-dumping investigations, and quality standards in conditions of sustainably high turnover of environmentally intensive raw materials. Crude oil and petroleum products account for $80 \%$ of the almost twofold growth of Russian supplies to other BRICS countries (by $80 \%$ in 2009-2014). ${ }^{27}$

At the same time, given the differentiation of the BRICS countries in terms of quality of growth and sensitivity to external shocks, if they diversify exports (of oil and petroleum products from Russia and China) or protect local producers from international competition (for agricultural products from Brazil and Russia), using "green economy" measures instead of raising tariffs for environmentally friendly goods can help maintain the levels of trade and economic relations.

\footnotetext{
${ }^{26}$ See more details at: ANNEX C - APEC List of Environmental Goods [APEC, 2012].

${ }^{27}$ Author's estimations based on data from International Trade Centre [n.d.].
} 


\section{References}

Anand R., Tulin V., Kumar N. (2014) India: Defining and Explaining Inclusive Growth and Poverty Reduction. IMF Working Paper 14/63, International Monetary Fund, Washington. Available at: https:// www.imf.org/external/pubs/ft/wp/2014/wp1463.pdf (accessed 10 October 2018).

APEC Leaders (2012) APEC Leaders' Declaration. ANNEX C. APEC List of Environmental Goods. Vladivostok, 8-9 September. Available at: https://www.apec.org/Meeting-Papers/Leaders-Declarations/2012/2012_aelm/2012_aelm_annexC (accessed: 10.10.2018).

Ares E., Bennett O., Bolton P. (2009) Climate Change: The Copenhagen Conference. Research Paper 09/87, House of Commons Library. Available at: researchbriefings.files.parliament.uk/documents/ RP09-87/RP09-87.pdf (accessed 10 October 2018).

Azevedo V.G., Simone S., Licis M.S. Campos (2018) CO2 Emissions: A Quantitative Analysis Among BRICS Nations. Renewable and Sustainable Energy Reviews, vol. 81, pp. 107-15.

Bernasconi-Osterwalder N., Magraw D., Oliva M.J., Tuerk E., Orellana M. (2012) Environment and Trade: A Guide to WTO Jurisprudence. London: Earthscan.

BRICS (n.d.) Concept of the Russian Federation's Presidency in BRICS in 2015-2016. Official Website of Russia's Presidency in BRICS. Available at: http://en.brics2015.ru/russia_and_brics/20150301/19483. html (accessed 10 October 2018).

BRICS Leaders (2014) Fortaleza Declaration, 15 July. Available at: http://www.ranepa.ru/images/media/brics/brazpresidency2/6th_BRICS_Summit_Fortaleza_Declaration_and_Action_Plan.pdf (accessed 7 March 2018).

BRICS Leaders (2015) Ufa Declaration, 9 July. Available at: http://www.ranepa.ru/images/media/brics/ ruspresidency2/Declaration_eng.pdf (accessed 10 March 2018).

Government of India Ministry of Environment and Forests (2011) Sustainable Development in India: Stocktaking in the Run up to Rio+20.

Government of India Prime Minister's Office (2015) Joint Statement on Climate Change Between India and China During Prime Minister's Visit to China. 15 May. Available at: http://pib.nic.in/newsite/PrintRelease.aspx?relid=121754 (accessed 10 October 2018).

Climate Action Network (n.d.) Available at: http://infoclimate.org (accessed 10 October 2018).

Food and Agriculture Organization of the United Nations (FAO) (n.d.) Food and Agriculture Data. Available at: http://www.fao.org/faostat/en/\#home (accessed 10 October 2018).

Food and Agriculture Organization of the United Nations (FAO) (2014a) State of the World's Forests: Enhancing the Socioeconomic Benefits from Forests. Available at: http://www.fao.org/policy-support/ resources/resources-details/en/c/418450/ (accessed 10 October 2018).

Food and Agriculture Organization of the United Nations (FAO) (2014b) Thirteen Countries Move Closer to Eradicating Hunger. Available at: http://www.fao.org/news/story/en/item/270380/icode/ (accessed 10 October 2018).

Food and Agriculture Organization of the United Nations (FAO) (2016) State of the World's Forests: Land-Use Challenges and Opportunities. Available at: http://www.fao.org/publications/sofo/2016/en/ (accessed 10 October 2018).

Food Security Portal (n.d.) Available at: http://www.foodsecurityportal.org/ (accessed 10 October 2018).

Fosu A.K. (2010) Inequality, Income and Poverty: Comparative Global Evidence. BWPI Working Paper 140, Brooks World Poverty Institute, Helsinki.

International Monetary Fund (IMF) (n.d.) Data Mapper: Real GDP Growth. Available at: www.imf.org/ external/datamapper/index.php (accessed 10 October 2018). 
International Monetary Fund (IMF) (2018) Brighter Prospects, Optimistic Markets, Challenges Ahead. World Economic Outlook Update, January. Available at: https://www.imf.org/en/Publications/WEO/ Issues/2018/01/11/world-economic-outlook-update-january-2018 (accessed 7 April 2018).

International Trade Centre (ITC) (n.d) Trade Map. Available at: http://www.trademap.org/Index.aspx (accessed 10 October 2018).

International Trade Centre (ITC) (2015) Building Sustainable Supply Chains: Trade for Sustainable Development. Available at: http://www.intracen.org/uploadedFiles/intracenorg/Content/Redesign/ Events/Aid4Trade/T4SD\%20Brochure-JAG-web_final\%2024-06-2015.pdf (accessed 10 October 2018).

Kadysheva O. (2013) Decision of the WTO Dispute Settlement Body in the Case of Brazil: Measures ffecting the import of Tires with a Retreaded Protector: The Trade Dispute is Over, and Dengue Fever Has Just Begun. Modern Law, no. 9, pp. 127-31. (in Russian)

Khmelevskaya N.G. (2014) International Commodity Organizations: Basic Principles and Instruments of Operational Activity: Textbook. Moscow: INFRA-M. (in Russian)

Khmelevskaya N.G. (2015a) Metamorphoses of Complementarity of Mutual Trade: BRICS and Export Positions of Member Countries. Issues of Economics, no 8, pp. 43-57. (in Russian)

Khmelevskaya N.G. (2015b) Russia's Foreign Trade Policy Priorities in the Orbit of BRICS Economic Cooperation: BRICS. Economic Policy, vol. 10, no 2, pp. 93-109 (in Russian).

Kono D.Y. (2017) Tariffs and Carbon Emissions. International Interactions, vol. 43, no 6, pp. 893-919.

Lustig N. (2015) Inequality and Fiscal Redistribution in Middle Income Countries: Brazil, Chile, Colombia, Indonesia, Mexico, Peru and South Africa. CGD Working Paper 410, Center for Global Development, Washington. Available at: https://www.cgdev.org/publication/inequality-and-fiscal-redistribution-middle-income-countries-brazil-chile-colombia (accessed 10 October 2018).

Makarov I.A., Sokolova A.K. (2014) Estimation of the Carbon Intensity of Russia's Foreign Trade. Economic Journal of the Higher School of Economics. vol. 18, no 3, pp. 477-507. (in Russian)

Organisation for Economic Co-operation and Development (OECD) (n.d.) Statistical Database. Available at: http://stats.oecd.org/_(accessed 10 October 2018).

Organisation for Economic Co-operation and Development (OECD) (2015) In It Together: Why Less Inequality Benefits All. Paris: OECD Publishing.

Okuneva L.S. (2008) Brazil: Features of the Democratic Project: Pages of the Newest Political History of the Latin American Giant (1960s-2006). Moscow State Institute of International Relations University, Ministry of Foreign Affairs of Russia. Moscow: MGIMO-University. (in Russian)

Pan C., Peters G.P., Andrew R.M., Korsbakken J.I., Li S., Zhou D., Zhou P. (2017) Emissions Embodied in Global Trade Have Plateaued Due to Structural Changes in China. Earth's Future, vol. 5, pp. 934-46. Available at: https://agupubs.onlinelibrary.wiley.com/doi/pdf/10.1002/2017EF000625 (accessed 10 October 2018)

The World Integrated Trade Solution (WITS) (n.d.) Available at: https://wits.worldbank.org/ (accessed 10 October 2018).

United Nations (n.d.a) Millennium Development Goals Indicators. United Nations Statistics Division. Available at: http://mdgs.un.org/unsd/mdg/Data.aspx (accessed 10 October 2018).

United Nations (n.d.b) Sustainable Development Goals. Available at: https://www.un.org/sustainabledevelopment/ru/\# (accessed 10 October 2018).

United Nations (1992a) Rio de Janeiro Declaration on Environment and Development. Rio de Janeiro, 3-14 June.

United Nations (1992b) UN Conference on Environment and Development. Available at: http://www. un.org/geninfo/bp/enviro.html (accessed 10 October 2018).

United Nations (UN) (2002) Report of the International Conference on Financing for Development. Monterrey, 18-22 March. A/CONF.198/8/. Available at: https://www.cepal.org/noticias/noticias/2/10582/aconf198-11ing.pdf (accessed 10 October 2018). 
United Nations (UN) (2015) Framework Convention on Climate Change. Paris, 30 November - 11 December. FCCC/CP/2015/L.9. Available at: https://sustainabledevelopment.un.org/frameworks/parisagreement (accessed 10 October 2018).

United Nations Conference on Trade and Development (UNCTAD) (2013) Non-Tariff Measures to Trade: Economic and Policy Issues for Developing Countries. Available at: https://unctad.org/en/PublicationsLibrary/ditctab20121_en.pdf (accessed 10 October 2018).

United Nations Development Program (UNDP) (n.d.) Global Human Development Indicators. Available at: http://hdr.undp.org/en/countries (accessed 10 October 2018).

United Nations Environment Program (UNEP) - International Institute for Sustainable Development (IISD) (2005) Environment and Trade: A Handbook. Second edition. Available at: https://www.iisd.org/ pdf/2005/envirotrade_handbook_2005.pdf (accessed 10 October 2018).

United Nations Environment Program (UNEP) - International Institute for Sustainable Development (IISD) (2014) Trade and Green Economy: A Handbook. Third edition. Available at: https://www.iisd. org/library/trade-and-green-economy-handbook-third-edition (accessed 10 October 2018).

United Nations General Assembly (1987) Development and International Economic Cooperation: Environmental Problems. Report of the World Commission on Environment and Development. Note by the Secretary-General. A/42/427.

United Nations General Assembly (2001) Letter Dated 19 November 2001 from the Permanent Representative of Qatar to the United Nations, Addressed to the Secretary-General. A/C.2/56/7.

United Nations General Assembly (2012) The Future We Want. Resolution Adopted by the General Assembly on 27 July. A/RES/66/288. Available at: http://www.un.org/en/development/desa/population/ migration/generalassembly/docs/globalcompact/A_RES_66_288.pdf (accessed 10 October 2018).

United Nations Statistics Division (UNSD) (n.d.) Available at http://unstats.un.org (accessed 10 October 2018).

World Summit on Sustainable Development (2002) Johannesburg Declaration on Sustainable Development. 4 September. A/CONF.199/20. Available at: http://www.un-documents.net/jburgdec.htm (accessed 10 October 2018).

World Trade Organization (WTO) (n.d.a) General Agreement on Tariffs and Trade 1994. Available at: https://www.wto.org/english/docs_e/legal_e/06-gatt_e.htm (accessed 10 October 2018).

World Trade Organization (WTO) (n.d.b) Agreement on Subsidies and Countervailing Measures. Available at: https://www.wto.org/english/docs_e/legal_e/24-scm_01_e.htm (accessed 10 October 2018).

World Trade Organization (WTO) (1996) United States - Standards for Reformulated and Conventional Gasoline: Report of the Appellate Body. WT/DS2/9. Available at: https://www.wto.org/english/ tratop_e/dispu_e/2-9.pdf (accessed 10 October 2018).

World Trade Organization (WTO) (2009) Brazil - Measures Affecting Imports of Retreaded Tyres: Dispute Settlement. WT/DS332. Available at: https://www.wto.org/english/tratop_e/dispu_e/cases_e/ ds332_e.htm (accessed 10 October 2018).

World Trade Organization (WTO) (2011) Harnessing Trade for Sustainable Development and a Green Economy. Available at: https://www.wto.org/english/res_e/publications_e/brochure_rio_20_e.pdf (accessed 10 October 2018). 


\title{
Контуры диалога БРИКС по устойчивому развитию в реалиях внешнеторговых отношений ${ }^{1}$
}

\author{
Н.Г. Хмелевская
}

Хмелевская Наталья Геннадьевна - к.э.н., доцент кафедры «Банки, денежное обращение и кредит» МГИМО (У) МИД России; Российская Федерация, 119454, Москва, просп. Вернадского, д. 76; E-mail: Khmelevskaya@mgimo.ru

Статья посвящена формированию контура многостороннего диалога БРИКС для целей решения проблем качества развития с опорой на наиболее демонстративную сферу их экономического сотрудничества - взаимную торговлю. Внешнеполитический контур диалога БРИКС - это разделенная ответственность и национальные обязательства в рамках системы ООН, ВТО и т.д. Поскольку его сопряжение со стратегиями развития происходит в разных средах и на различных скоростях, сближение позиций стран БРИКС - как вне, так и внутри объединения - идет в русле их внутриэкономических приоритетов, а значит, и включение механизмов многостороннего сотрудничества в национальные планы развития инклюзивно. Внешнеэкономический контур - это схожие ограничения внутреннего развития, основанные на эксплуатации природных ресурсов в сельскохозяйственных и обрабатывающих производствах, использование грязных видов топлива, экологически емкий экспорт и общая необходимость сохранения и восстановления ресурсной базы.

Аналитическую основу исследования составили количественные параметры взаимной торговли БРИКС за 2009-2017 гг., показатели ресурсоемкости экспорта БРИКС, статистика нетарифных ограничений. Сохраняя в сырьевых отраслях относительно схожую и по общему уровню низкую тарифную нагрузку, БРИКС регулируют оборот «зеленых» товаров внутри объединения с помощью технических барьеров, мер ценового контроля и стандартов качества при устойчиво высокой доле экологически емкого сырья. Вместе с тем в условиях дифференциации стран БРИКС по качеству роста и чувствительности к внешним шокам одни страны диверсифицируют свой экспорт (нефть и продукты ее переработки из России и Китая), другие защищают местных производителей (сельхозпродукция из Бразилии и России), а меры «зеленой экономики» взамен повышения тарифов на экологически чистые товары помогают удержать рынки.

Ключевые слова: БРИКС; Цели устойчивого развития (ЦУР); взаимная торговля; меры «зеленой экономики»; нетарифные ограничения; экологически емкий экспорт

Для цитирования: Хмелевская Н.Г. (2018) Контуры диалога БРИКС по устойчивому развитию в реалиях внешнеторговых отношений // Вестник международных организаций. Т. 13. № 4. С. 74-95 (на русском и английском языках). DOI: 10.17323/1996-7845-2018-04-04.

\section{Источники}

Генеральная Ассамблея ООН (1987) Развитие и международное экономическое сотрудничество: проблемы окружающей среды. Доклад Всемирной комиссии по вопросам окружающей среды и развития. Записка Генерального секретаря. А/42/427.

Генеральная Ассамблея ООН (2001) Письмо постоянного представителя Катара при ООН от 19 ноября 2001 г. на имя Генерального секретаря. А/С.2/56/7.

Генеральная Ассамблея ООН (2012) Резолюция «Будущее, которого мы хотим». A/RES/66/288. Режим доступа: http://www.un.org/en/development/desa/population/migration/generalassembly/docs/global compact/A_RES_66_288.pdf (дата обращения: 10.10.2018).

\footnotetext{
${ }^{1}$ Статья поступила в редакцию в апреле 2018 г.
} 
ООН (1992) Рио-де-Жанейрская декларация по окружающей среде и развитию. Рио-де-Жанейро, 3-14 июня.

OOH (2002) Доклад международной конференции по финансированию развития. A/CONF.198/8/ Add. 4. Монтеррей, 18-22 марта.

ООН (2015) Рамочная конвенция об изменении климата. Париж, 30 ноября - 11 декабря. FССС/ CP/2015/L.9.

ФАО (2014а) Тринадцать стран приблизились к цели искоренения голода. 13 ноября. Режим доступа: http://www.fao.org/news/story/ru/item/270396/icode/ (дата обращения: 10.10.2018).

ФАО (2014b) Состояние лесов мира: приумножение социально-экономических выгод, обеспечиваемых лесами. Режим доступа: http://www.fao.org/policy-support/resources/resources-details/en/c/418450/ (дата обращения: 10.10.2018).

ФАО (2016) Состояние лесов мира: проблемы и возможности землепользования. Режим доступа: http://www.fao.org/publications/sofo/2016/ru/ (дата обращения: 10.10.2018).

Кадышева О. (2013) Решение Органа по рассмотрению споров ВТО по делу Бразилия - меры, затрагивающие импорт шин с восстановленным протектором: торговый спор завершен, а лихорадка денег только началась // Современное право. № 9. С. 127-131.

Макаров И.А., Соколова А.К. (2014) Оценка углеродоемкости внешней торговли России // Экономический журнал ВШЭ. Т. 18. № 3. С. 477-507.

Окунева Л.С. (2008) Бразилия: особенности демократического проекта: Страницы новейшей политической истории латиноамериканского гиганта (1960-е гг. - 2006 г.). МГИМО (У) МИД России. М.: МГИМО-Университет.

Хмелевская Н.Г. (2014) Международные отраслевые организации: базовые принципы и инструментарий операционной деятельности: учеб. пособие. М.: ИНФРА-М.

Хмелевская Н.Г. (2015а) Метаморфозы дополняемости взаимной торговли БРИКС и экспортные позиции стран-членов // Вопросы экономики. № 8. С. 43-57.

Хмелевская Н.Г. (2015b) Приоритеты внешнеторговой политики России в орбите экономического сотрудничества БРИКС // Экономическая политика. Т. 10. № 2. С. 93-109.

Anand R., Tulin V., Kumar N. (2014) India: Defining and Explaining Inclusive Growth and Poverty Reduction. IMF Working Paper 14/63, Washington. Режим доступа: https://www.imf.org/external/pubs/ft/ wp/2014/wp1463.pdf (дата обращения: 10.10.2018).

APEC Leaders (2012) APEC Leaders' Declaration. ANNEX C. APEC List of Environmental Goods. Vladivostok, 8-9 September. Режим доступа: https://www.apec.org/Meeting-Papers/Leaders-Declarations/2012/2012_aelm/2012_aelm_annexC (дата обращения: 10.10.2018).

Ares E., Bennett O., Bolton P. (2009) Climate Change: The Copenhagen Conference. Research Paper 09/87, House of Commons Library. Режим доступа: http://researchbriefings.files.parliament.uk/documents/RP0987/RP09-87.pdf (дата обращения: 10.10.2018).

Azevedo V.G., Sartori S., Campos L.M.S. (2018) CO2 Emissions: A Quantative Analysis among BRICS Nations // Renewable and Sustainable Energy Reviews. Vol. 81. P. 107-115.

Bernasconi-Osterwalde N., Magraw D., Oliva M.J., Tuerk E., Orellana M., Roch P. (2012) Environment and Trade: A Guide to WTO Jurisprudence. L.: Routledge.

BRICS (n.d.) Concept of the Russian Federation's Presidency in BRICS in 2015-2016. Official Website of Russia's Presidency in BRICS. Official Website of Russia's Presidency in BRICS. Режим доступа: http:// brics2015.ru/russia_and_brics/20150301/15383.html (дата обращения: 20.10.2018).

BRICS Leaders (2014) Fortaleza Declaration. 15 June. Режим доступа: http://www.ranepa.ru/images/ media/brics/brazpresidency2/6th_BRICS_Summit_Fortaleza_Declaration_and_Action_Plan.pdf (дата обращения: 07.03.2018).

BRICS Leaders (2015) Ufa Declaration. 9 Jule. Режим доступа: http://www.ranepa.ru/images/media/brics/ ruspresidency2/Declaration_eng.pdf (дата обращения: 10.03.2018).

Government of India Ministry of Environment and Forests (2011) Sustainable Development in India: Stocktaking in the Run up to Rio+20. 
Bureau Government of India Prime Minister's Office (2015) Joint Statement on Climate Change between India and China during Prime Minister's visit to China, 15 May.

Climate Action Network (n.d.) Режим доступа: http://infoclimate.org (дата обращения 10.10.2018).

Food and Agriculture Organization of the United Nations (FAO) (n.d.) Food and Agriculture Data. Режим доступа: http://www.fao.org/faostat/en/\#home (дата обращения: 10.10.2018).

Food Security Portal (n.d.) Режим доступа: http://www.foodsecurityportal.org/ (дата обращения: 10.10.2018).

Fosu A.K. (2010) Inequality, Income, and Poverty: Comparative Global Evidence. BWPI Working Paper 140, Brooks World Poverty Institute, Helsinki.

International Monetary Fund (IMF) (n.d.) Data Mapper: Real GDP Growth. Режим доступа: www.imf.org/ external/datamapper/index.php (дата обращения: 10.10.2018).

International Monetary Fund (IMF) (2018) World Economic Outlook Update. Washington DC, January. Режим доступа: https://www.imf.org/en/Publications/WEO/Issues/2018/01/11/world-economic-outlookupdate-january-2018 (дата обращения: 7.04.2018).

International Trade Centre (ITC) (n.d.) Trade Мар. Режим доступа: http://www.trademap.org/Index.aspx (дата обращения: 10.10.2018).

International Trade Centre (ITC) (2015) Building Sustainable Supply Chains: Trade for Sustainable Development, Geneva. Режим доступа: http://www.intracen.org/uploadedFiles/intracenorg/Content/Redesign/ Events/Aid4Trade/T4SD\%20Brochure-JAG-web_final\%2024-06-2015.pdf (дата обращения: 10.10.2018).

Kono D.Y. (2017) Tariffs and Carbon Emissions // International Interactions. Vol. 43. No. 6. P. 895-919.

Lusting N. (2015) Inequality and Fiscal Redistribution in Middle Income Countries: Brazil, Chile, Colombia, Indonesia, Mexico, Peru and South Africa. CGD Working Paper 410, Center for Global Development, Washington.

Organisation for Economic Co-operation and Development (OECD) (n.d.) Statistical Database. Режим доступа: http://stats.oecd.org/ (дата обращения: 10.10.2018).

Organisation for Economic Co-operation and Development (OECD) (2015) In It Together: Why Less Inequality Benefits All. Paris: OECD Publishing.

Pan C., Peters G.P., Andrew R.M., Korsbakken J.I., Li S., Zhou D., Zhou P. (2017) Emissions embodied in global trade have plateaued due to structural changes in China // Earth's Future. Vol. 5. P. 934-946.

The World Integrated Trade Solution (WITS) (n.d.) Режим доступа: https://wits.worldbank.org/ (дата обращения 10.10.2018).

United Nations (n.d.a) Millennium Development Goals Indicators. United Nations Statistics Division. Режим доступа: http://mdgs.un.org/unsd/mdg/Data.aspx (дата обращения: 10.10.2018).

United Nations (n.d.b) Sustainable Development Goals. Режим доступа: https://www.un.org/sustainabledevelopment/ru/\# (дата обращения: 10.10.2018).

United Nations (1992b) UN Conference on Environment and Development. Режим доступа: http://www. un.org/geninfo/bp/enviro.html (дата обращения: 10.10.2018).

United Nations Conference on Trade and Development (UNCTAD) (2013) Non-tariff Measures to Trade: Economic and Policy Issues for Developing Countries. Режим доступа: https://unctad.org/en/PublicationsLibrary/ditctab20121_en.pdf (дата обращения: 10.10.2018).

United Nations Development Program (UNDP) (n.d.) Global Human Development Indicators. Режим доступа: http://hdr.undp.org/en/countries (дата обращения: 10.10.2018).

United Nations Environment Program (UNEP) - International Institute for Sustainable Development (IISD) (2005) Environment and Trade: A Handbook. Second edition. Режим доступа: https://www.iisd.org/ pdf/2005/envirotrade_handbook_2005.pdf (дата обращения: 10.10.2018).

United Nations Environment Program (UNEP) - International Institute for Sustainable Development (IISD) (2014) Trade and Green Economy: A Handbook. Third edition. Режим доступа: https://www.iisd.org/library/ trade-and-green-economy-handbook-third-edition (дата обращения: 10.10.2018). 
United Nations Statistics Division (UNSD) (n.d.) Режим доступа: http://unstats.un.org (дата обращения: 10.10.2018).

World Summit on Sustainable Development (2002) Johannesburg Declaration on Sustainable Development. 4 September. A/CONF.199/20. Режим доступа: http://www.un-documents.net/jburgdec.htm (дата обращения: 10.10.2018).

World Trade Organization (WTO) (n.d.a) General Agreement on Tariffs and Trade 1994. Режим доступа: https://www.wto.org/english/docs_e/legal_e/06-gatt_e.htm (дата обращения: 10.10.2018).

World Trade Organization (WTO) (n.d.b) Agreement on Subsidies and Countervailing Measures. Available at: https://www.wto.org/english/docs_e/legal_e/24-scm_01_e.htm (дата обращения: 10.10.2018).

World Trade Organization (WTO) (1996) United States - Standards for reformulated and Conventional Gasoline: Report of the Appellate Body. WT/DS2/9. Режим доступа: https://www.wto.org/english/tratop_e/ dispu_e/2-9.pdf (дата обращения: 10.10.2018).

WTO (2009) Brazil - Measures affecting imports of retreaded tyres. Dispute Settlement. WT/DS332. Режим доступа: https://www.wto.org/english/tratop_e/dispu_e/cases_e/ds332_e.htm (дата обращения: 10.10.2018).

WTO (2011) Harnessing trade for sustainable development and a green есоnomy. Режим доступа: https:// www.wto.org/english/res_e/publications_e/brochure_rio_20_e.pdf (дата обращения: 10.10.2018). 